the clinical characteristics, treatment, outcome and damage of patients with adult IgA Vasculitis.

Methods: We assembled a retrospective cohort of patients with adult IgA Vasculitis from tertiary Rheumatology Centres in Turkey. The demographics, clinical characteristics, treatment and outcomes of patients were abstracted from medical records. Birmingham Vasculitis Activity Score (BVAS), prognostic Five Factor Score (FFS) and vasculitis damage index (VDI) were calculated.

Results: The study included 103 (male/female: 67/36) patients with adult IgA Vasculitis. The mean age was $42.6 \pm 17$ years. Infection history within 6 weeks before presentation was present in $40(38.8 \%)$ patients (32 upper respiratory tract, 3 urinary tract, 2 gastrointestinal, 3 others). Cutaneous manifestations and arthritis/arthralgia were the most common clinical manifestations (table 1). 92 (89.3\%) patients were treated with oral glucocorticoids (GC). Pulse GC treatment was also given to $29(28.1 \%)$ patients. As additional immunosuppressive agents, azathioprine was given to $36(34.9 \%)$ and pulse cyclophosphamide to $13(12.6 \%)$ patients. Fifty-nine patients $(58.2 \%)$ had follow-up of mean 35.6 months. Eleven $(18.6 \%)$ patients relapsed during follow-up. While 5 relapses were major, six of them were minor relapses. At the last visit, disease status was evaluated as active or treatment failure by the treating physician in $7(11.8 \%)$ patients. The rate of chronic renal failure was $8.3 \%(n=5)$. Mortality was $1.6 \%(n=1)$ during follow-up, due to pneumonia. The mean VDI score was 0.3 in the last visit. Twelve (20.3\%) patients had at least one damage item at the end of follow-up period.

Abstract AB0661 - Table 1. Baseline clinical characteristics of patients with adult Henoch Schönlein Purpura

\begin{tabular}{|c|c|}
\hline & $\begin{array}{l}\text { Adult Henoch Schönlein Purpura } \\
\text { (n=103) }\end{array}$ \\
\hline \multicolumn{2}{|l|}{\begin{tabular}{|l} 
Laboratory parameters \\
\end{tabular}} \\
\hline Anemia $(<12 \mathrm{mg} / \mathrm{dl}$ for female, $13 \mathrm{mg} / \mathrm{d}$ f for male) $(\mathrm{n}, \%)$ & $36(35 \%)$ \\
\hline \begin{tabular}{|l} 
Evythrooyte Sedimentation Rate $(\mathrm{mm} / \text { /hour })^{*}$ \\
\end{tabular} & $34.7 \pm 22$ \\
\hline \begin{tabular}{|l|l|l|l|l} 
C.reactive protein $\left(\mathrm{mg} / \mathrm{I}^{+}\right.$ \\
\end{tabular} & $18(1-297)$ \\
\hline \begin{tabular}{|l|} 
Proteinuria ( $2300 \mathrm{mg} / 24$ hours) \\
\end{tabular} & $47(45.6 \%)$ \\
\hline Creatinine $\left(\mathrm{m}_{\mathrm{g} / \mathrm{d} d)^{*}}\right.$ & $0.8+0.3$ \\
\hline Hepatitis B posititivity (n) & $8 / 97(8.2 \%)$ \\
\hline Hepatitis C positivity (n) & 0/97 \\
\hline ANA positivity & $21 / 97(21.7 \%)$ \\
\hline RE Positivity & $5 / 88(5.78)$ \\
\hline \begin{tabular}{|l} 
CANCA positivity \\
\end{tabular} & $2 / 97(2.18)$ \\
\hline \begin{tabular}{|l} 
P-ANCA positivity \\
\end{tabular} & $1 / 95(1.1 \%)$ \\
\hline \multicolumn{2}{|l|}{ Clinical Manifestations, $\mathrm{n} / 103(\%)$} \\
\hline \begin{tabular}{|l|l|l|l|l|l|l|l} 
Fever \\
\end{tabular} & $24(23.3 \%)$ \\
\hline \begin{tabular}{|l|l|l} 
Weight loss \\
\end{tabular} & $26(25.26)$ \\
\hline \begin{tabular}{|l} 
Mralgia/Weakness/Leg tenderness \\
\end{tabular} & $44(42.7 \%)$ \\
\hline \begin{tabular}{|l|} 
Arthritis and/or arthralgia \\
\end{tabular} & $87(84.5 \%)$ \\
\hline \begin{tabular}{|l|} 
Neurologic manifestations \\
\end{tabular} & $1(0.986)$ \\
\hline \begin{tabular}{|l} 
Testicular pain or tenderness \\
\end{tabular} & $4(3.96)$ \\
\hline \begin{tabular}{|l|} 
Recent onset or severe hypertension \\
\end{tabular} & $2(1.96)$ \\
\hline \begin{tabular}{|l} 
Cutaneous Manifestations \\
\end{tabular} & $97(94.296)$ \\
\hline \begin{tabular}{|l|} 
Peripheral limb edema \\
\end{tabular} & $14(13.6 \%)$ \\
\hline \begin{tabular}{|l} 
Gastrointestinal manifestations \\
\end{tabular} & $71(68.920)$ \\
\hline \begin{tabular}{|l|} 
Cardiac manifestations \\
\end{tabular} & $5(4.8 \%)$ \\
\hline \begin{tabular}{|l|} 
Ocular manifiestations \\
\end{tabular} & $3(2.986)$ \\
\hline \begin{tabular}{|l} 
Pulmonarymanifestations \\
\end{tabular} & $3(2.96)$ \\
\hline FFS $=0$ & $71(68.99)$ \\
\hline FFS $=1$ & $24(23.396)$ \\
\hline FFS $=2$ & $5(4.996)$ \\
\hline FFS $=3$ & $3(2.996)$ \\
\hline \begin{tabular}{|l|l} 
BVAS score at diagnosis* \\
\end{tabular} & $6 \pm 3$ \\
\hline
\end{tabular}

ANA: Anti nuclear antibody, FR: Rheumatoid factor, ANCA: Antineutrophilic cytoplasmic antibody, FFS: Five Factor Score, BVAS: Birmingham Vasculitis Activity score. *Mean \pm SD $\nmid$ Median(Minimum-maximum)

Conclusions: Our results showed that approximately one fifth of patients with adult $\lg \mathrm{A}$ Vasculitis had relapses during follow-up and had at least one damage item at the end of follow-up. Although, $31 \%$ of patients had FFS $\geq 1$, the mortality rate was observed to be very low in the present study.

Disclosure of Interest: None declared

DOI: 10.1136/annrheumdis-2018-eular.4869

\section{AB0662 SUBGLOTTIC STENOSIS IN GRANULOMATOSIS WITH POLIANGIITIS}

C.E. Pena ${ }^{1}$, F. Giordano ${ }^{2}$, L. Garcia ${ }^{1}$, C. Costi ${ }^{1}$, G. Pendon ${ }^{2}$, A. Vulcano ${ }^{1}$, D. Pereira ${ }^{1}$, M. Garcia ${ }^{1}{ }^{1}$ Rheumatology, HIGA San Martin La Plata;

${ }^{2}$ Rheumatology, Hospital Gutierrez La Plata, La Plata, Argentina

Background: The characteristic lesion of laryngotracheal involvement in granulomatosis with polyangiitis (GPA) is subglottic stenosis (SGS), due to active disease or from chronic recurrent inflammation, $8 \%$ to $23 \%$ during the course of GPA and as initial manifestation in $1 \%$ to $6 \%$ of cases.

Objectives: Describe clinical features and treatment of patients with SGS

Methods: We retrospectively reviewed the medical records of 46 patients with SGS due to GPA diagnosed at a Rheumatology department (2000-2017). We retrospectively reviewed the medical records of 46 patients with SGS due to GPA diagnosed at a Rheumatology department (2000-2017).
Results: 6/46 patients with GPA diagnosis presented SGS (13\%). 83\% women, mean age of 37.8 years ( $D S \pm 14.8$ ). Mean time between the presentation of the GPA and the diagnosis of SGS:18 months. Most frequent clinical manifestations of SGS: dyspnea (83\%), stridor (83\%), dysphonia (50\%), cough $(33 \%)$, bronchospasm (16\%). One patient presented SGS as initial manifestation of the disease. Mean BVAS:14. Two patients presented such complication with evidence of systemic manifestations. Re stenosis was observed in one patient.

Treatment: IV CYC 83\%, oral CYC 16\%, methylprednisolone (MP) $83 \%$, oral steroids, plasma exchange (16\%) in each one. Endoscopic intervention and balloon dilatation33\%, and intralesional Mitomycin 16\%.

Conclusions: $13 \%$ patients with GPA presented SGS, being in the majority of cases associated with other manifestations of the disease. However, $67 \%$ had no signs of systemic involvement (localised disease). Local treatment was necessary in only $33 \%$ because there was a good response to IS in $67 \%$ of the cases.

\section{REFERENCE:}

[1] G. Horta-Baas, et al. Subglottic stenosis in granulomatosis with polyangiitis (Wegener's granulomatosis): Report of 4 cases.Reumatol Clin. 2016;12 (5):267-273. (Surgical interventions and local therapy for Wegener's granulomato)

Disclosure of Interest: None declared

DOI: 10.1136/annrheumdis-2018-eular.3977

\section{AB0663 18F-FDG-PET/CT DISEASE DISTRIBUTION IN A LARGE VESSEL VASCULITISCOHORT - SUPPORTS VASCULAR ULTRASOUND AS A SCREENING AND DIAGNOSTIC TOOL}

F. Coath ${ }^{1}$, F. Laskou ${ }^{1}$, S. Moghul ${ }^{2}$, A. Sidhu ${ }^{1}$, S. Banerjee ${ }^{1}$, T. Aung ${ }^{1}$, S. Jain ${ }^{2}$, J. Mo ${ }^{2}$, B. Dasgupta ${ }^{1} .{ }^{1}$ Rheumatology; ${ }^{2}$ Radiology, Southend University Hospital, Westcliff-On-Sea, UK

Background: Subsets of GCA have extensive vascular involvement, termed Large Vessel GCA (LV-GCA), seen in 12\%-37\% depending on imaging used. These patients have higher relapse rates and are more often refractory to glucocorticoids (GC), requiring steroid-sparing treatment to minimise GC toxicity and vascular complications. Diagnosis is reliant upon imaging, given the relative inac cessibility of tissue for histological analysis beyond temporal artery biopsy (TAB). If axillary and subclavian arteries are often affected, vascular ultrasound could be an effective screening tool.

Objectives: To determine disease distribution in the Southend Large Vessel Vas culitis (LVV) cohort, particularly levels of axillary and subclavian involvement. Methods: The cohort has sixty-five patients (2010-2017), from which sixty ${ }^{18} \mathrm{~F}$ FDG-PET/CT scans were performed. They were retrospectively examined by two nuclear radiologists. Vascular involvement was determined by consensus opinion at six territories (thoracic-aorta, abdominal-aorta, subclavian, axillary, carotid, vertebral, and iliac and femoral). Six negative scans were excluded from analysis, with LVV confirmed from other evidence (ultrasound, computed tomography). Of these, four were on concurrent GC (7-12 mg prednisolone), raising the possibility of "false negatives". Nineteen scans were positive despite GC (1-60 mg prednisolone). Higher doses tended to be of short duration, being unable to postpone due to clinical necessity, but exceeded the 3 day limit at which FDG signal starts to attenuate.

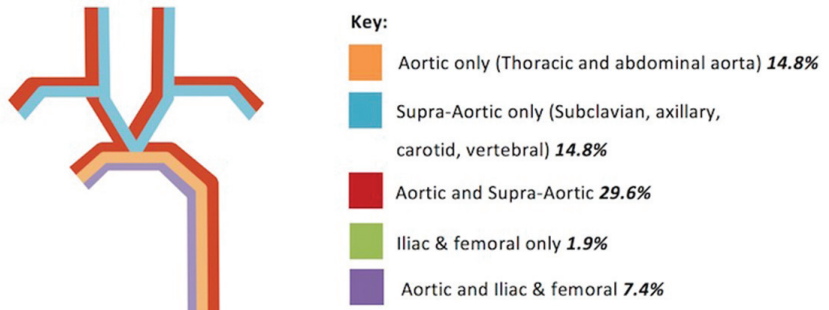

Involvement of all regions in $\mathbf{3 1 . 5 \%}$

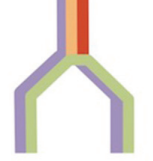

Abstract AB0663 - Figure 1. Disease distribution via ${ }^{18} \mathrm{~F}-\mathrm{FDG}-\mathrm{PET} / \mathrm{CT}$

Results: $14.8 \%(n=8)$ had isolated supra-aortic disease, $14.8 \%(n=8)$ had isolated aortic disease, and $29.6 \%(n=16)$ had involvement in both (Fig 1). $72.2 \%$ of 
Abstract AB0662 - Table 1

\begin{tabular}{|c|c|c|c|c|c|c|c|}
\hline Case & $\begin{array}{c}\text { Sex/Age at } \\
\text { diagnosis of SGS }\end{array}$ & $\begin{array}{l}\text { Time from diagnosis } \\
\text { (months) }\end{array}$ & $\begin{array}{l}\text { Manifestations } \\
\text { of SGS }\end{array}$ & $\begin{array}{l}\text { Manifestations of } \\
\text { vasculitis/BVAS }\end{array}$ & ANCA & $\begin{array}{c}\text { Treatment } \\
\text { Induction (I) } \\
\text { Mantainance (M) }\end{array}$ & Evolution \\
\hline 1 & $W / 20$ & 12 & $\begin{array}{c}\text { Stridor } \\
\text { Dysphonya } \\
\text { Bronschospasm } \\
\text { Dyspnoea }\end{array}$ & $\begin{array}{l}\text { No systemic } \\
\text { manifestations } \\
\text { BVAS: } 6\end{array}$ & MPO & $\begin{array}{l}\text { I: IV CYC+IV steroids } \\
\text { M: MTX+oral steroids }\end{array}$ & Resolution \\
\hline 2 & $\mathrm{M} / 42$ & 3 & $\begin{array}{l}\text { Dysphonia } \\
\text { Dyspnoea }\end{array}$ & $\begin{array}{l}\text { Glomerulonephritis } \\
\text { Interstitial lung } \\
\text { disease } \\
\text { Pulmonary nodules } \\
\text { Otitis } \\
\text { Rhinosinusitis } \\
\text { Saddle nose } \\
\text { Mononeuritis } \\
\text { BVAS: } 33\end{array}$ & PR3 & $\begin{array}{l}\text { I:IV CYC+MP } \\
\text { M: AZA }\end{array}$ & $\begin{array}{l}\text { Infectious complications } \\
\text { Gammaglobulin Treatment }\end{array}$ \\
\hline 3 & W/35 & 6 & $\begin{array}{l}\text { Dyspnoea } \\
\text { Stridor }\end{array}$ & $\begin{array}{l}\text { Pulmonary nodules } \\
\text { Rhinosinusitis } \\
\text { Saddle nose } \\
\text { Crusting } \\
\text { BVAS: } 9\end{array}$ & PR3 & $\begin{array}{c}\text { I: oral } \mathrm{CYC}+\text { oral steroids } \\
\mathrm{M}: \mathrm{MTX}+ \\
\text { Oral steroids }\end{array}$ & Resolution \\
\hline 4 & W/67 & 24 & $\begin{array}{l}\text { Stridor } \\
\text { Dysphonia } \\
\text { Cough }\end{array}$ & $\begin{array}{l}\text { Crusting } \\
\text { Rhinosinusitis } \\
\text { Otitis } \\
\text { Mononeuritis } \\
\text { BVAS: } 17\end{array}$ & PR3 & $\begin{array}{c}\text { I: IV CYC+MP } \\
\text { M: AZA } \\
\text { Local treatment: dilatation with } \\
\text { balloon }\end{array}$ & $\begin{array}{l}\text { Restenosis with immunosuppression. Resolution } \\
\text { with local treatment }\end{array}$ \\
\hline 5 & W/27 & 24 & $\begin{array}{l}\text { Dyspnoea } \\
\text { Stridor }\end{array}$ & $\begin{array}{c}\text { Sensorineural hearing } \\
\text { loss } \\
\text { Artritis } \\
\text { Rhinosinusitis } \\
\text { Crusting } \\
\text { Pulmonary nodules } \\
\text { BVAS: } 10\end{array}$ & PR3 & $\begin{array}{c}\text { I: MP+IV } \\
\text { CYC } \\
\text { Plasma exchange } \\
\text { Balloon dilatation and } \\
\text { intralesional Mitomycin C }\end{array}$ & $\begin{array}{l}\text { Re stenosis with immunosuppression. Resolution } \\
\text { with local local treatment }\end{array}$ \\
\hline 6 & $W / 36$ & 24 & $\begin{array}{l}\text { Cough } \\
\text { Dyspnoea } \\
\text { Stridor }\end{array}$ & $\begin{array}{l}\text { Pulmonary nodules } \\
\text { BVAS: } 9\end{array}$ & $\mathrm{C}(\mathrm{IFI})$ & $\begin{array}{c}\text { I: IV CYC+MP } \\
\text { M: oral steroids local dilatation } \\
\text { with balloon }\end{array}$ & Resolution \\
\hline
\end{tabular}

scans had involvement at either or both of the axillary and subclavian territories. Femoral and iliac involvement alone was seen in $1.9 \%(\mathrm{n}=1)$, and in addition to aortic involvement in $7.4 \%(n=4)$. In this latter group, it was limited to the abdominal aorta in half, and included 1 case of Retroperitoneal Fibrosis. $31.5 \%(n=17)$ had involvement in all 3 regions. $24.1 \%(n=13)$ had no supra-aortic involvement. Conclusions: This cohort demonstrates LVV has a predilection for aortic and supra-aortic regions. High axillary and subclavian involvement supports the use of vascular ultrasound as an effective imaging tool. Further imaging would still be warranted if suspicion remained high despite negative ultrasound, or to assess for vascular complications and alternate pathology. ${ }^{18} \mathrm{~F}-\mathrm{FDG}-\mathrm{PET} / \mathrm{CT}$ is not without limitations. Atherosclerosis and vascular remodelling display increased FDG uptake, so requires cautious interpretation. Further research on GC influence is also needed. As such it has a role in monitoring flaring or non-responsive patients, rather than routine interval scanning. For the latter, ultrasound may be an alternative, especially if there is previously documented intimal-medial thickening at ultrasound accessible sites.

\section{REFERENCES:}

[1] Dejaco C, Brouwer E, Mason JC, Buttgereit F, Matteson EL, Dasgupta B. Giant cell arteritis and polymyalgia: current challenges and opportunities. Nature Reviews Rheumatology. 2017;13(10):578-92.

[2] Blockmans D, Thorsten B, Schmidt W. Imaging for large-vessel vasculitis. Current Opinions in Rheumatology. 2009;21(1):19-28.

Disclosure of Interest: None declared

DOI: 10.1136/annrheumdis-2018-eular.5222

\section{AB0664 LIFE EXPECTANCY IN PATIENT WITH GIANT CELL ARTERITIS (GCA): IMPACT OF VISION LOSS}

G.S. Breuer ${ }^{1,2,3}$, V. Poltorak ${ }^{1,3}$, R. Nesher ${ }^{4}$, G. Nesher ${ }^{1,2,3} .{ }^{1}$ Hebrew University, School of Medicine; ${ }^{2}$ Medicine; ${ }^{3}$ Rheumatology, Shaare Zedek Medical Center, Jerusalem; ${ }^{4}$ Ophtalmology, Meir Medical Center, Kfar Saba, Israel

Background and purpose: Several epidemiologic studies reported increased mortality in patients with GCA, while others found that the overall survival was essentially identical to that of the general population. Those studies used different methods to calculate the mortality rates.

Objectives: In this retrospective study we evaluated longevity in a group of GCA patients using specific gender and age-matched life expectancy tables.
Methods: Medical records of patients diagnosed with GCA in one Medical Centre between 1980-1999 were reviewed for clinical parameters at the time of diagnosis and during the first year of treatment, and for time of death and cause of death. All patients diagnosed as GCA during that time period have already passed away. For each patient the observed survival was compared with the specific age and gender-matched life expectancy in the general population, based on life expectancy tables of the Israel Central Bureau of Statistics.

Results: 87 patients (51 females, 36 males) were included, their mean age at the time of GCA diagnosis was $73.9 \pm 8.4$ and $75 \pm 8.1$ years, respectively. The calculated mean life expectancy for this group of patients, from the time of diagnosis, was $14.1 \pm 6$ years for females and $12 \pm 5.2$ for males. However, the actual survival was significantly shorter, $7.5 \pm 6.2$ years $(p<0.001)$ in females, and $7.7 \pm 7.3$ years $(p=0.005)$ in males. Survival was not significantly affected by the intensity of inflammation at the time of diagnosis (based on the presence of fever, anaemia, sedimentation rate above $100 \mathrm{~mm} / \mathrm{h}$, thrombocytosis and leukocytosis), by the daily dose of prednisone at 1 year, or by the use of low-dose aspirin during the first year. However, vision loss at the time of presentation $(n=13)$, was associated with further decrease in survival, $4.1 \pm 4.4$ years compared to $8.3 \pm 6.8$ years in GCA patients with no vision loss $(p=0.035)$. Causes of death were defined in 54 patients. The leading causes of death were cardiovascular/cerebrovascular diseases, in $43 \%$ of the patients, slightly exceeding the respective rate in the agematched general population ( $40 \%, p=0.8)$, and infectious diseases, in $37 \%$ of the patients, significantly exceeding the respective rate in the age-matched general population $(22 \%, \mathrm{p}=0.015)$.

Conclusion: Infectious diseases were often the cause of mortality In this group of GCA patients, relative to the background population. Survival following GCA diagnosis was significantly shorter than expected, especially in patients presenting with vision loss.

Disclosure of Interest: None declared

DOI: 10.1136/annrheumdis-2018-eular.2391

\section{AB0665 INTERSTITIAL LUNG DISEASE AMONG PATIENTS WITH GIANT CELL ARTERITIS}

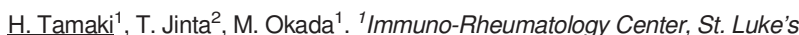
International Hospital; ${ }^{2}$ Pulmonary Medicine, St Luke's International Hospital, Tokyo, Japan

Background: Lately interstitial lung disease (ILD) has been recognised more and more as a manifestation of primary systemic vasculitis, particularly among patients with microscopic polyangiitis (MPA), which is predominantly a disease of the elderly in Japan. Another primary systemic vasculitis that occurs frequently in 